\title{
Palatabilitas pakan ternak ruminansia berimbuhan antelmintika
}

\author{
Aji Winarso*, Dede Rival Novian, Dewi Fesbayati Lestari Djungu \\ Fakultas Kedokteran Hewan, Universitas Nusa Cendana, Penfui, Kota Kupang, Nusa Tenggara Timur
}

\begin{abstract}
ABSTRAK: Kendala-kendala dalam pengobatan ternak seperti yang telah disebutkan dapat memboroskan waktu, tenaga, obat-obatan, dan mungkin berisiko bagi keselamatan. Administrasi obat yang kurang sempurna juga berisiko membuat pengobatan di bawah dosis efektif (under dose) sehingga memicu resistensi. Untuk meningkatkan efisiensi dan efektivitas pengobatan ternak, maka perlu dilakukan inovasi dalam sediaan obat menjadi sediaan pakan berimbuhan. Dengan demikian administrasi obat dilakukan secara voluntary per oral. Penelitian ini bertujuan untuk mengetahui palatabilitas pakan berimbuhan berupa biskuit dengan beberapa golongan antelmintika yaitu albendazole, piperazine citrate dan levamisole. Biskuit dasar dibuat dari bahan dedak gandum yang direkatkan dengan bubur kanji dan maizena. Biskuit pakan berimbuhan dijemur dibawah terik matahari selama dua hari dan diberikan kepada hewan coba sesuai dosis anjuran. Sediaan biskuit dirancang untuk dosis pemberian 1 biskuit per $20 \mathrm{~kg}$ BB. Hasil penelitian menunjukkan bahwa pencampuran antelmintik kepada pakan berupa biskuit dedak gandum menghasilkan pakan berimbuhan memiliki palatabilitas yang baik untuk ketiga antelmintika yaitu albendazole, piperazine citrate, dan levamisole.

Kata kunci:

biskuit pakan, kecacingan, pakan berimbuhan, resistensi antelmintika, ruminansia
\end{abstract}

\section{- PENDAHULUAN}

Kendala yang dihadapi dalam upaya peningkatan produktivitas ternak diantaranya adalah infeksi parasit cacing. Sementara itu, peternak di Nusa Tenggara Timur (termasuk di Kabupaten Kupang) pada umumnya memberi makan sapi dengan cara digembalakan. Ternak yang digembalakan lebih rentan terinfeksi parasit cacing dan protozoa serta berpeluang lebih banyak untuk terpapar ektoparasit vektor penyakit (Bilal et al. 2009). Prosedur pemberian obat antiparasit per oral sering kali terkendala akibat peringai sapi bali yang dipelihara secara semi intensif sebagaimana di NTT menyebabkan ternak sapi cenderung menjadi lebih agresif. Selain mengurangi angka keberhasilan prosedur, hal ini dapat mengancam keselamatan peternak/petugas. Sementara itu, pengobatan per oral pada kambing sedikit menyita waktu dan mungkin bahan obat karena kambing dapat melontarkan obat yang sudah dimasukkan ke dalam mulut.

Kendala-kendala dalam pengobatan ternak seperti yang telah disebutkan dapat memboroskan waktu, tenaga, obatobatan, dan mungkin berisiko bagi keselamatan petugas/peternak. Di samping itu, pengobatan yang kurang sempurna mungkin akan membuat kadar obat yang masuk berada di bawah dosis efektif (under dose) dan memicu terjadinya resistensi (Shalaby 2013; De Graef et al. 2013). Untuk meningkatkan efisiensi dan efektivitas pengobatan ternak, maka perlu dilakukan inovasi dalam sediaan obat. Inovasi yang dimaksud adalah dengan mengemas sediaan obat menjadi sediaan pakan, sehingga administrasi obat dilakukan secara voluntary oleh hewan. Hal ini dapat dimungkinkan karena sediaan obat memiliki palatabilitas yang serupa dengan palatabilitas pakan. Pengemasan obat cacing dalam campuran pakan sebagai pakan berimbuhan diduga dapat menjadi salah satu solusi. Penelitian ini bertujuan untuk mengetahui palatabilitas pakan berimbuhan dengan beberapa golongan antelmintika yaitu albendazole, piperazine citrate dan levamisole.

\section{- BAHAN DAN METODE}

Waktu dan Tempat Penelitian: Penelitian dilakukan di Fakultas Kedokteran Hewan Universitas Nusa Cendana bulan Agustus-September 2018.

Hewan Percobaan: Percobaan menggunakan 5 ekor hewan yang terdiri dari 2 ekor domba dewasa, 2 ekor kambing dewasa dan 1 ekor anak kambing. Tidak ada kelompok kontrol dalam percobaan ini, umumnya domba sangat menyukai bran gandum dan tidak memakan obat dalam bentuk kapsul atau bolus secara voluntir.

Penyiapan Biskuit Berimbuhan Antelmintika: Biskuit pakan dibuat dari bahan dedak gandum yang direkatkan dengan bubur kanji dan maizena. Bubur perekat dibuat dengan memasak suspensi $40 \mathrm{~g}$ kanji dan $20 \mathrm{~g}$ maizena dalam $400 \mathrm{ml}$ air. Setelah bubur perekat dingin, kemudian ditambahkan dengan $400 \mathrm{~g}$ dedak gandum. Adonan pakan ini kemudian ditambahkan satu sediaan antelmintika dalam

\footnotetext{
Diterima: 23-10-2018 | Direvisi: 06-11-2018 | Disetujui: 09-11-2018

(C) 2018 CC-BY-SA. Ini adalah artikel Open Access yang didistribusikan berdasarkan ketentuan dari Creative Commons Attribution ShareAlike 4.0 International License (https://creativecommons.org/licenses/by-sa/4.0/).
} 
bentuk serbuk atau gerusan. Untuk pembuatan biskuit berimbuhan albendazole, adonan pakan ditambahkan alnbendazole (Wormzol-B ${ }^{\circledR}$ Medion) sebesar $1500 \mathrm{mg}$. Prosedur yang sama dilakukan untuk membuat adonan yang ditambahkan antelmintik berbeda, masing-masing $60 \mathrm{~g}$ piperazine citrate (Contra-Worm ${ }^{\circledR}$ Pyridam Veteriner) dan $1500 \mathrm{mg}$ Levamisole $\mathrm{HCl}$ (Nemasole Kaplet ${ }^{\circledR}$ Medion). Adonan pakan berimbuhan kemudian dicetak dengan kempa masing-masing menjadi 10 biskuit dan dikeringkan dengan dijemur selama 2 hari (Gambar 1).

Pengujian Palatabilitas: Biskuit pakan berimbuhan (yang telah dijemur dua hari) diberikan kepada hewan coba sesuai dosis anjuran pabrik yang juga masih sesuai dengan dosis menurut literatur (Adams 2001; Bowman 2009) (dosis pemberian 1 biskuit per $20 \mathrm{~kg} \mathrm{BB}$ ). Kemudian diamati apakah biskuit dimakan oleh hewan coba atau tidak, serta dihabiskan atau tidak.

Analisis Data: Data pengamatan palatabilitas pakan berimbuhan ini disajikan secara deskriptif.

\section{- HASIL DAN PEMBAHASAN}

Gambar 1 menunjukkan biskuit yang telah dibuat dan digunakan dalam penelitian ini. Retnani et al. (2011) membuat biskuit pakan ternak dengan metode kempa dan dioven. Penelitian ini tidak menggunakan oven karena dikhawatirkan dapat merusak struktur kimiawi antelmintika yang ditambahkan. Namun dengan metode cetak adonan dalam penelitian ini, biskuit dapat hancur ketika digigit.

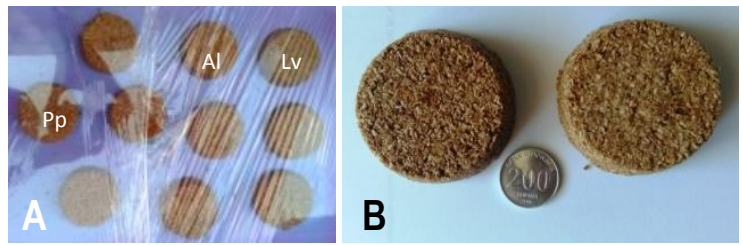

Gambar 1 Sediaan biskuit pakan memiliki tampilan yang serupa untuk semua jenis obat yang ditambahkan. (A) Penjemuran biskuit pakan: Pp: piperazine, Al: albendazole, Lv: levamisole, (B) Biskuit pakan yang telah kering

Palatabilitas biskuit pakan merupakan karakteristik pakan yang menimbulkan rangsangan dan daya tarik bagi ternak untuk mengkonsumsi biskuit itu (Retnani et al. 2009). Karakteristik yang dimaksud merupakan sifat organoleptik meliputi warna, bau, tekstur, rasa (hambar, manis, asam, asin, dan pahit) dan temperatur.

Pengolahan dedak gandum menjadi biskuit telah mengubah tekstur serbuk menjadi padat, akan tetapi tidak mengubah warna, rasa, bau serta temperaturnya saat diberikan sebagai pakan. Penambahan antelmintika telah mengubah warna pakan menjadi kemerahan pada jenis piperazine citrate (Gambar 1). Penambahan antelmintik pada pakan juga dapat mengubah rasa pakan, mungkin ada yang menjadi agak pahit. Dari ketiga jenis antelmintika yang ditambahkan dalam biskuit, memiliki palatabilitas yang seragam. Palatabilitas biskuit pakan berimbuhan antelmintik tergolong baik. Biskuit pakan yang telah dikeringkan selama dua hari setelah pembuatan dimakan hingga habis oleh kambing dan domba (Gambar 2) dalam durasi yang hampir sama sekitar 20 hingga 30 detik.

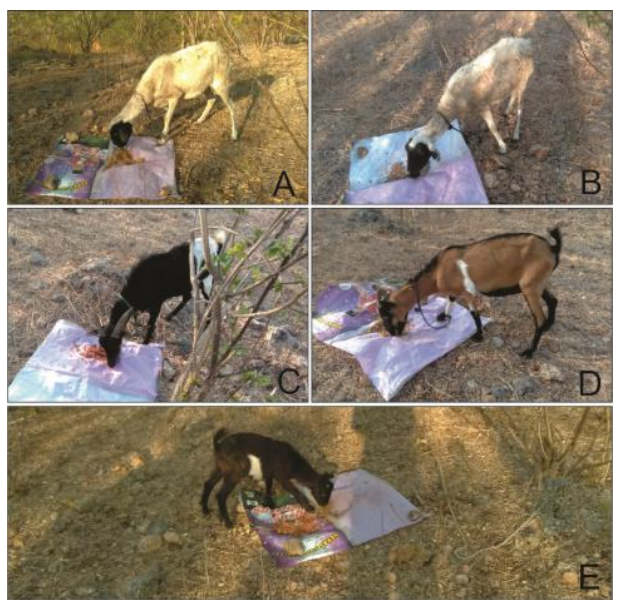

Gambar 2 Pengujian palatabilitas biskuit pakan berimbuhan antelmintika. (A, B) albendazole, (C, D) piperazine, (E) levamisole

\section{- SIMPULAN}

Pencampuran antelmintik kepada pakan berupa biskuit dedak gandum menghasilkan pakan berimbuhan memiliki palatabilitas yang baik bagi ketiga antelmintika yaitu albendazole, piperazine citrate, dan levamisole.

\section{— INFORMASI PENULIS}

Penulis untuk Korespondensi

*AW: ajiwinarso@staf.undana.ac.id

Fakultas Kedokteran Hewan, Universitas Nusa Cendana, Penfui, Kota Kupang, Nusa Tenggara Timur

\section{— UCAPAN TERIMA KASIH}

Penelitian ini dibiayai dengan dana DIPA Fakultas Kedokteran Hewan Universitas Nusa Cendana Tahun Anggaran 2018 melalui Surat Perintah Kerja (SPK) Penelitian Nomor 1097/UN15.17.2/TU/2018.

\section{- PUSTAKA ACUAN}

Adams HR. 2001. Veterinary Pharmacology and Therapeutics, $8^{\text {th }}$ Ed. Iowa: Iowa State University Press.

Bilal MQ, Hameed A, Ahmad T. 2009. Prevalence of gastrointestinal parasites in buffalo and cow calves in rural areas of Toba Tek Singh, Pakistan. J Anim Plant Sci. 19(2): 67-70.

Bowman DD. 2009. Georgi's Parasitology for Veterinarians. 9th ed. Missouri: Saunders Elsevier.

De Graef J, Claerebout E, Geldhof P. 2013. Anthelmintic resistance of gastrointestinal cattle nematodes. Vlaams Diergeneeskundig Tijdschrift. 8:113-123.

Retnani Y, Herawati L, Widarti W, Indahwati E. 2009. Uji sifat fisik dan palatabilitas biskuit limbah tanaman jagung sebagai substitusi sumber serat untuk domba. Buletin Peternakan. 33(3): 162-169.

Retnani Y, Wijayanti I, Kumalasari NR. 2011. Produksi biskuit limbah tanaman jagung sebagai pakan komersil ternak ruminansia. JIPI. 16 (1): 59-64.

Shalaby HA. 2013. Anthelmintics Resistance; How to Overcome it? Iranian J Parasitol. 8(1): 18-32.

Zajac AM, Conboy GA. 2012. Veterinary Clinical Parasitology. 8th ed. Iowa: John Wiley \& Sons. 
